\title{
Geenivirtatutkimus ristipölytteisillä kasveilla pelto-olosuhteissa
}

\author{
Maria Erkkilä ${ }^{1)}$, Ruslan Kalendar ${ }^{2)}$ ja Alan Schulman ${ }^{1,2)}$ \\ ${ }^{1)}$ MTT Biotekniikka- ja elintarviketutkimus, Kasvigenomiikka 31600 Jokioinen, \\ etunimi.sukunimi@mtt.fi \\ ${ }^{2)}$ MTT/BI Kasvigenomiikan laboratorio,00014 Helsingin yliopisto,etunimi.sukunimi@helsinki.fi
}

\section{Tiivistelmä}

Geenimuunneltujen (GM) lajikkeiden mahdollinen viljely Suomessa edellyttää ennakoivaa tutkimusta, jotta tavanomaisten, luonnonmukaisten ja geenimuunneltujen lajikkeiden rinnakkaiselo onnistuu eikä muunneltua geeniainesta siirry tai GM-lajike sekaannu GM-vapaaseen materiaaliin tuotantoprosessin aikana. Sekoittumista voi tapahtua tuotantoketjun joka vaiheessa aina pellolta lopputuotteen pakkaamiseen ja merkintään asti. Kuitenkin ongelmallisempana on pidettävä alkutuotannossa tapahtuvaa sekoittumista, koska se muodostaa tuotantoketjun ensimmäisen vaiheen. Siitepölyn leviämisen kautta tapahtuva geeniaineksen siirtyminen on erityinen riski ristipölytteisillä kasveilla (Brassica-suku).

Hankkeessa tutkittiin sekoittumisriskin todennäköisyyttä Suomen kasvuoloissa sekä kehitettiin menetelmäratkaisuja tilanteen hallitsemiseksi. Sekoittumisen seuraamiseksi kehitettiin herkkiä ja spesifisiä geenimerkkejä rypsin ja rapsin tunnistamiseen. Kokeet toteutettiin maksimaalisen riskin periaatteella käyttämättä kuitenkaan GM-lajikkeita, vaan riskejä arvioitiin tavanomaisten viljelyssä olevien lajikkeiden avulla. Geenimerkkejä käytettiin tutkittaessa geeniaineksen siirtymistä eri etäisyyksillä pelto-olosuhteissa kolmena perättäisenä kasvukautena 2004-2006.

Peltokokeissa noin 1 ha:n rapsi- ja 2 ha:n rypsipelto kylvettiin aivan rinnakkain. Lisäksi kylvettiin rypsistä näyteruutuja $100 \mathrm{~m}$ välein aina kilometrin päähän rapsipellosta. Pellolta kerättiin kasvukausien lopussa siemennäytteet, joista eristettiin DNA. Geenivirran tutkimiseksi kehitettiin retrotransposonipohjaiset geenimerkit sekä rapsin että rypsin genomille. Tässä tutkimuksessa käytetyt retrotransposonit eli toistojaksot esiintyvät genomissa monena kopiona ja oletettavasti useassa eri kromosomissa, joten ne ovat herkempiä kuin yhtenä kopiona genomissa olevat merkit. Geenimerkeillä tutkittiin mille etäisyydelle rapsin siitepöly voi kulkeutua eli kuinka kaukaa löydetään rypsin ja rapsin risteymiä.

Risteymiä, joissa näytteen sekoittumisaste oli yli $0,9 \%$ löytyi runsaasti $275 \mathrm{~m}$ :iin asti ja alle 0,4 \% sekoittumisasteella satunnaisesti aina kilometrin päästä rapsipellosta. Siitepölyn siirtymisen lajista toiseen mahdollisti rypsin ja rapsin osittain samanaikainen kukinta. Tuloksiin vaikuttivat myös käytetyt geenimerkit, kasvukausien sääolosuhteet ja muut ulkoiset tekijät, kuten mehiläisten, eläinten ja ihmisten aiheuttama siitepölyn leviäminen. Käytännössä ristisiittoisten kasvien kohdalla on mahdotonta välttää ristipölytystä, mutta EU:n säännöstön mukainen alle 0,9 \%:n sekoittumistaso voidaan saavuttaa. Geenivirtatutkimuksen perusteella voidaan todeta, että tavanomaisten, luonnonmukaisten ja geenimuunneltujen lajikkeiden rinnakkaiselon onnistumiseksi on huolehdittava riittävistä suojavyöhykkeistä, joiden leveyksiin vaikuttavat maaston muoto, tuulen suunta ja muiden lähellä olevien peltolohkojen kasvit.

Asiasanat: geenivirta, rapsi, rypsi, rinnakkaiselo 


\section{Johdanto}

EU:n lainsäädännön mukaan viljelijällä on oikeus valita viljeleekö hän tavanomaisia, luonnonmukaisia tai geenimuunneltuja kasveja. Kuitenkin viljelijä voi valita vain EU:ssa hyväksyttyjä GM-lajikkeita. Geenimuunneltujen (GM) lajikkeiden mahdollinen viljely Suomessa edellyttää ennakoivaa tutkimusta, jotta tavanomaisten, luonnonmukaisten ja geenimuunneltujen lajikkeiden rinnakkaiselo onnistuu eikä muunneltua geeniainesta siirry tai GM-lajike sekaannu GM-vapaaseen materiaaliin tuotantoprosessin aikana. Sekoittumista voi tapahtua tuotantoketjun joka vaiheessa aina pellolta lopputuotteen pakkaamiseen ja merkintään asti. Lopputuote on merkittävä, jos GM:n osuus on 0,9\%. Kuitenkin ongelmallisimpana on pidettävä alkutuotannossa tapahtuvaa sekoittumista, koska se muodostaa tuotantoketjun ensimmäisen vaiheen. Siitepölyn leviämisen kautta tapahtuva geeniaineksen siirtyminen on erityinen riski ristipölytteisillä kasveilla (esimerkiksi Brassica-suku).

Tunnetun GM-sovelluksen ollessa kyseessä voidaan sekoittuminen tavanomaiseen tai luomulajikkeeseen todeta monistamalla genomiin siirretty DNA PCR:1lä (polymerase chain reaction). Sekoittumisen osoittaminen vaikeutuu, jos ei tiedetä, mikä sovellus on kyseessä. Vaihtoehtona tällöin on tutkia kaikki ko. kasvin tunnetut GM-sovellukset, mikä on varsin työlästä tai käyttää muita geenimerkkejä geenivirran toteamiseksi.

Hankkeessa tutkittiin riskien todennäköisyyttä Suomen kasvuoloissa sekä kehitettiin menetelmäratkaisuja tilanteen hallitsemiseksi. Sekoittumisen seuraamiseksi kehitettiin herkkiä ja spesifisiä geenimerkkejä lajikkeiden tunnistamiseen. Tutkimuksessa käytettiin rypsiä ja rapsia GMriskien arvioinnin mallikasveina. Kokeet toteutettiin maksimaalisen riskin periaatteella käyttämättä kuitenkaan GM-lajikkeita, vaan riskejä arvioitiin tavanomaisten viljelyssä olevien lajikkeiden avulla. Geenimerkkejä käytettiin tutkittaessa geeniaineksen siirtymistä eri etäisyyksillä pelto-olosuhteissa kolmena perättäisenä kasvukautena 2004-2006.

\section{Aineisto ja menetelmät}

Tutkimuksessa käytetyt lajikkeet olivat Wildcat-rapsi sekä Hohto- ja Kulta-rypsi. Peltokokeissa noin 1 ha rapsi- ja 2 ha rypsipelto kylvettiin aivan rinnakkain vuosina 2004, 2005 ja 2006. Lisäksi kylvettiin rypsistä näyteruutuja $100 \mathrm{~m}$ välein aina kilometrin päähän rapsipellosta tuulen alapuolelle. Isosta pellosta kerättiin kasvukausien lopussa siemennäytteet $100 \mathrm{~m}^{2}: \mathrm{n}$ alalta rapsipellosta poispäin metrin välein $5 \mathrm{~m}$ :in asti ja $10 \mathrm{~m}: n$ välein $100 \mathrm{~m}$ :iin asti sekä rapsipellon suuntaisesti $20 \mathrm{~m}: n$ välein. Jokaisesta kerätystä näytteestä laskettiin 3000 siementä, joista eristettiin DNA.

Geenivirran tutkimiseksi kehitettiin retrotransposonipohjaiset geenimerkit sekä rapsin (AACC) että rypsin (AA) genomille (kuva 1). Peltonäytteet tutkittiin tavallisella PCR:llä käyttäen 4 rapsispesifistä ja 2 rypsi-spesifistä geenimerkkiä. Lisäksi yhdestä rapsi-spesifisestä geenimerkistä tehtiin kvantitatiivinen PCR -sovellus. Tässä tutkimuksessa käytetyt retrotransposonit eli toistojaksot esiintyvät genomissa monena kopiona ja oletettavasti useassa eri kromosomissa, joten ne ovat herkempiä kuin yhtenä kopiona genomissa olevat merkit. Geenimerkeillä tutkittiin mille etäisyydelle rapsin siitepöly voi kulkeutua eli kuinka kaukaa löydetään rapsin ja rypsin risteymiä.

\section{Tulokset ja tulosten tarkastelu}

Ensinnäkin havaittiin, että tulosten toistettavuuteen vaikuttaa suuresti DNA:n laatu, koska huonosti puhdistettu DNA hajoaa säilytettäessä. Toiseksi havaittiin, että käytettäessä tavallista PCRmenetelmää käytetty geenimerkki vaikuttaa sekoittumisasteeseen. Tutkittaessa saman vuoden peltonäytteitä eri geenimerkeillä havaittiin hyvinkin poikkeavia esiintymiä risteymissä (kuva 2). Kolmanneksi havaittiin kasvukauden olosuhteiden vaikutus geenivirtaan. Verrattaessa eri vuosien tuloksia huomattiin, että v. 2004 todennäköisesti sateinen ja viileä kasvukausi aiheutti siitepölyn laskeutumisen lähelle rapsipeltoa. Vähemmän herkällä geenimerkillä 106 saatiin eniten risteymiä vuoden 2004 näytteillä myös kauemmaksi rapsipellosta. Muina vuosina tämä merkki antoi vain muutaman positiivisen tuloksen hyvin lähelle rapsipellon reunaa. Geenimerkillä 106 saatiin selvä vaste mehiläisistä kun taas herkemmällä merkillä 112 tämä mehiläisten vaikutus jäi ihmisen vaikutuksen varjoon (kuva 2). Kaikkein herkimmällä merkillä koko alue oli lähes täynnä risteymiä.

Tavallisella PCR:1lä löydettiin risteymiä aina kilometrin päästä siitepölynlähteenä olleesta rapsipellosta. Tavallisella PCR:1lä tulos on kvalitatiivinen eli nähdään onko rypsipellosta kerätyssä näytteessä rapsi-DNA:ta vai ei. Kvantitatiivisella PCR:llä saadaan selville mikä on rapsi-DNA:n suhteellinen osuus koko näytteen DNA-pitoisuudesta. 


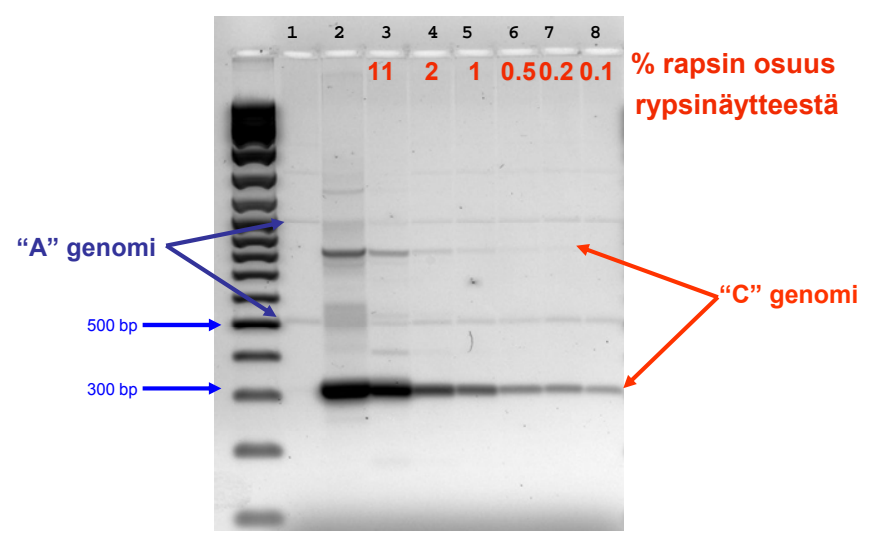

Kuva 1. Retrotransposonipohjaisen geenimerkin 106 herkkyys. EtBr-värjätyt PCR-näytteet ajettuna agaroosigeelillä. Näyte 1) $100 \%$ rypsi-DNA, 2) $100 \%$ rapsi-DNA, 3) - 8) 11 - 0,1 \% rapsi-DNA:ta rypsinäytteessä.

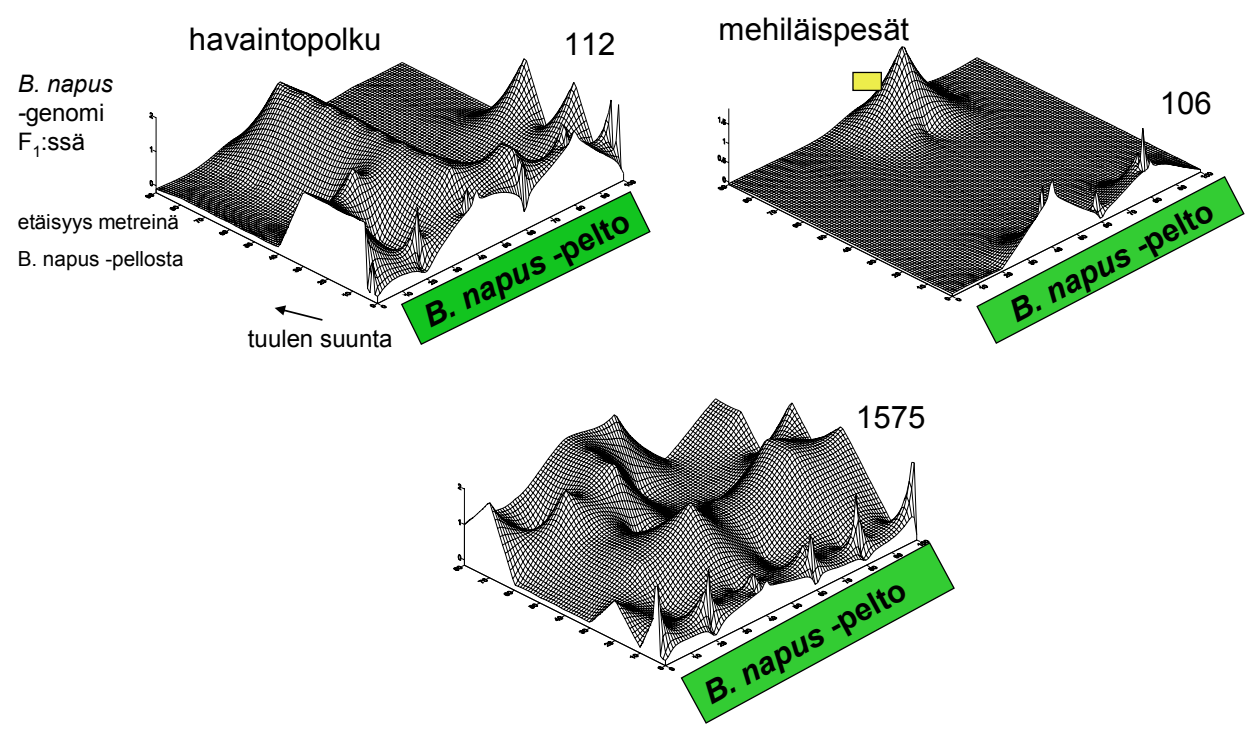

Kuva 2. Geenimerkkien herkkyyksien vertailu sekä olosuhteiden vaikutus geenivirtaan. Vuoden 2005 peltokokeen geenivirtatulokset $100 \mathrm{~m}^{2}$ alalta. Vihreä alue merkitsee rapsipellon reunaa. Piikkien huiput osoittavat rypsipellosta löytyneiden risteymien kohdat.

Kaikkein herkimmälle geenimerkille tehtiin myös kvantitatiivinen PCR -sovellus. Tällä menetelmällä löydettiin risteymiä, joissa näytteen sekoittumisaste oli yli $0,9 \%$ runsaasti $275 \mathrm{~m}$ :in asti ja satunnaisesti alle 0,4\% sekoittumisasteella v. 2005 kilometrin ja v. 2006 noin 700 m:n päästä rapsipellosta (kuva 3). 


\section{Geenimerkki (1574 + 1575)}
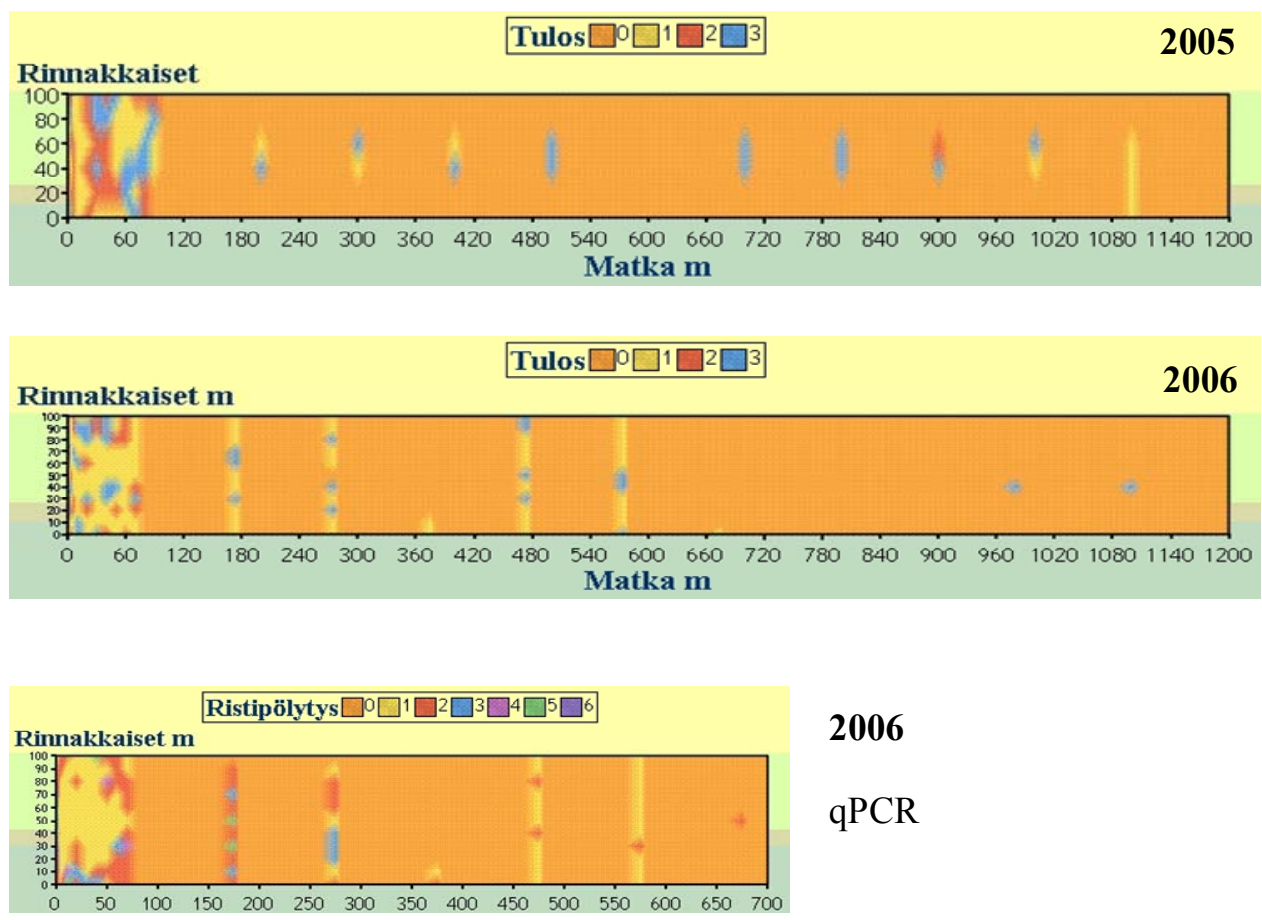

2006

qPCR

Kuva 3. Vuosien 2005 ja 2006 peltokokeiden geenivirtatulokset geenimerkillä $(1574+1575)$. Kuvassa rypsipelto ja koeruudut on merkitty 1 keltaisella, koeruutujen välissä kasvanut vilja on merkitty 0 oranssilla. Siitepölyn lähteenä ollut rapsipelto ei näy kuvassa, mutta se sijaitsi aivan rypsipellon vieressä 0-linjan vasemmalla puolella. Ylemmissä kuvissa punainen ja sininen väri osoittavat kyseisen kohdan rypsisiemennäytteestä löytyneen rapsi-DNA:ta. Alimmassa qPCR-kuvassa värit osoittavat sekoittumisasteen eli sen montako \% rapsi-DNA:ta löytyi rypsipellosta kerätyistä näytteistä: 2 punainen $0,1-0,40 \% ; 3$ sininen $0,41-$ $0,90 \% ; 4$ pinkki 0,91 - 1,80\%; 5 vihreä 1,81 - 3,70\%; 6 violetti > 3,71\%. qPCR = quantitative PCR.

\section{Johtopäätökset}

Siitepölyn siirtymisen lajista toiseen mahdollisti rypsin ja rapsin osittain samanaikainen kukinta. Tuloksiin vaikuttivat myös käytetyt geenimerkit, kasvukausien sääolosuhteet ja muut ulkoiset tekijät, kuten mehiläisten ja ihmisten aiheuttama siitepölyn leviäminen. Käytännössä ristisiittoisten kasvien kohdalla on mahdotonta välttää ristipölytystä, mutta alle 0,9 \%:n sekoittumistaso voidaan saavuttaa.

Geenivirtatutkimuksen perusteella voidaan todeta, että tavanomaisten, luonnonmukaisten ja geenimuunneltujen lajikkeiden rinnakkaiselon onnistumiseksi on huolehdittava riittävistä suojavyöhykkeistä, joiden leveyteen vaikuttavat maaston muoto, tuulen suunta ja muiden lähellä olevien peltolohkojen kasvit. 